\title{
GEOMORPHOSITE ASSESSMENT IN THE PROPOSED GEOPARK VISTULA RIVER GAP (E POLAND)
}

\author{
Justyna Warowna, Wojciech Zgłobicki, Grzegorz Gajek, Mągorzata Telecka, \\ Renata KoŁodyńsKa-GawrysiaK, PaweŁ Zieliński
}

Faculty of Earth Sciences and Spatial Management, Maria Curie-Skłodowska University, Lublin, Poland

Manuscript received: May 30, 2014

Revised version: July 28, 2014

\begin{abstract}
Warowna J., ZgŁobicki W., Gajek G., Telecka M., KoŁodyńsKa-Gawrysiak R., Zielinski P., 2014. Geomorphosite assessment in the proposed Geopark Vistula River Gap (E Poland). Quaestiones Geographicae 33(3), Bogucki Wydawnictwo Naukowe, Poznań, pp. 173-180, 3 tables, 3 figs. DOI 10.2478/quageo-2014-0040, ISSN 0137-477X.

AвSTRACT: Geomorphosites are among major assets for the development of geotourism. An accurate assessment of spatial distribution of their scientific, educational and economic characteristics provides the basis for appropriate design and management of proposed geoparks. Although the problem of assessing their value for geotourism has been discussed by numerous authors, consistent methodology for the assessment of geomorphosites has not been devised so far. In the present study, we conducted a geotourist evaluation of geomorphosites located within the proposed geopark Vistula River Gap. We assessed a total of 76 sites using 18 assessment criteria. The results indicate not uniform spatial distribution of sites having the highest value. The application of cluster analysis to evaluation results enabled us to distinguish groups of sites with similar characteristics and thus to identify groups of geomorphosites in relation to which various measures should be taken in order to increase the possibilities of their tourist use.
\end{abstract}

KEYWORDS: geomorphosites, geopark, geotourism, Vistula River Gap

Address of the corresponding author: Justyna Warowna, Faculty of Earth Sciences and Spatial Management, Maria CurieSkłodowska University, al. Kraśnicka 2cd, 20-718 Lublin, Poland; e-mail: jwarowna@umcs.pl

\section{Introduction}

The scientific, tourist and education evaluation of geomorphosites is indispensable in the process of effective management of geoheritage resources. The identification of sites with the highest value makes it possible to plan and implement suitable protection and popularisation measures as well as to expand tourist infrastructure.

Geomorphosites are defined as landforms to which a specific value has been attributed by human beings in the perception process (Panizza 2001). From the perspective of tourists, geomorphosites seem to be the most interesting element of geoheritage because, aside from their scientific value they usually have high aesthetic (scenic) value that is quite significant from the perspective of tourist valuation (Zgłobicki et al. 2005, Reynard et al. 2007). Hence geomorphosites are highly significant for geotourism.

Attempts to assess the value of abiotic sites on the national scale were already made in the 1990s (Alexandrowicz et al. 1992). Due to the large territorial scope of the study, the valuation was simplified and based on three criteria only (scientific value), assessed according to a three-point scale. The valuation of sites listed in the Polish Central Register of Geosites had a similar, general character (Warowna et al. 2013). Numerous geotourist valuations were also attempted on a regional scale (Solarska, Jary 2010, Dmytrowski, Kicińska 2011, Radwanek-Bąk, Laskowicz 2012). 
The following criteria are applied in geosite assessments most frequently: scientific, tourist, aesthetic, economic and educational value. The number of characteristics taken into account in various methods varies and uniform procedures have not been developed yet (cf. a review paper by Kubaliková 2013). The methods of valuation are usually based on numerical score evaluation which attempts to move away from qualitative to quantitative analysis. This method, however, is not objective because the selection of characteristics and the weight ascribed to the particular methods is subjective (Necheş 2013). Survey methods are also used to assess the tourist attractiveness of geomorphosites (Zgłobicki, Baran-Zgłobicka 2013).

The objective of this study was to present and verify the method developed for the geotourist valuation of geomorphosites and its practical application in the area of the proposed geopark Vistula River Gap. On this basis, key challenges associated with the proper use of the tourist potential and space in the study area were identified. Therefore, we used grouping methods that had already been used in a study on management priorities for the Pyrenees National Park (Feuillet, Sourp 2011).

\section{Study area}

The valuation concerned the inventoried geomorphosites in the proposed Geopark Vistula River Gap (Geopark Małopolski Przełom Wisły - GMPW). The project conducted by the GMPW Consortium (Maria Curie-Skłodowska University, Warsaw University, Polish Geological Institute-National Research Institute), commissioned by the Ministry of the Environment and funded by the National Fund for Environmental Protection and Water Management (NFOSiGW), involved selection of 220 sites as geosites of tourist significance, including 93 geological sites, 76 geomorphosites, 14 hydrographic sites and 37 other sites (including viewpoints) and additional 131 cultural sites. The proposed GMPW is located in mid-eastern Poland, in the upland belt of central Poland. The geopark encompasses the entire middle Vistula River Gap (from Zawichost to Puławy), sections of the western mesoregions of the Lublin Upland and a small part of the
Lubartów Plateau in the lowland belt. To the west of the Vistula valley, the upland part is represented by the narrow belts of the Iłża Foreland and Opatów Upland, and a small part of the Radom Plain in the lowland belt. From the geological perspective, the entire area is within the Lublin section of the Marginal Trought (Pożaryski 1997) referred to as the Puławy Trought in more recent studies (Narkiewicz, Dadlez 2008). In terms of administrative division, the proposed geopark encompasses the border areas of three provinces - Lubelskie, Mazowieckie and Świętokrzyskie including 13 municipalities located on the Vistula and seven neighbouring municipalities. The area of the planned geopark exceeds $1240 \mathrm{~km}^{2}$.

Geoparks are usually established in areas under various existing forms of protection. The following forms of protection currently characterize in the GMPW: two landscape parks, three areas of protected landscape, seven Natura 2000 areas and six nature reserves established mainly to protect animate nature but also, indirectly, landform features.

The following landform types occur in the area: the valley of a large river having the character of a gap (characteristics of a braided channel and meandering palaeochannels) with a floodplain and the system of higher terraces; deeply incised tributary valleys of erosional character; the valley having the characteristics of an ice-marginal valley; loess plateaus with erosional gully forms; glacial and fluvioglacial accumulation (upland and lowland) plains with their characteristic landforms; and denudation plains with exposed Upper Cretaceous deposits. Dunes are quite a common landform feature in the valley bottom and on post-glacial plains. The individual landscape patches are often separated from one another by distinct escarpments of considerable relative heights and varied origin (accumulation, erosion, denudation and tectonic origin) (Harasimiuk et al. 2013).

\section{Methods}

In this study, we used a modified method developed by Kubaliková (2013) based on an analysis of the methods published so far (e.g. Panizza 2001, Pralong 2005, Reynard et al. 2007). Accord- 

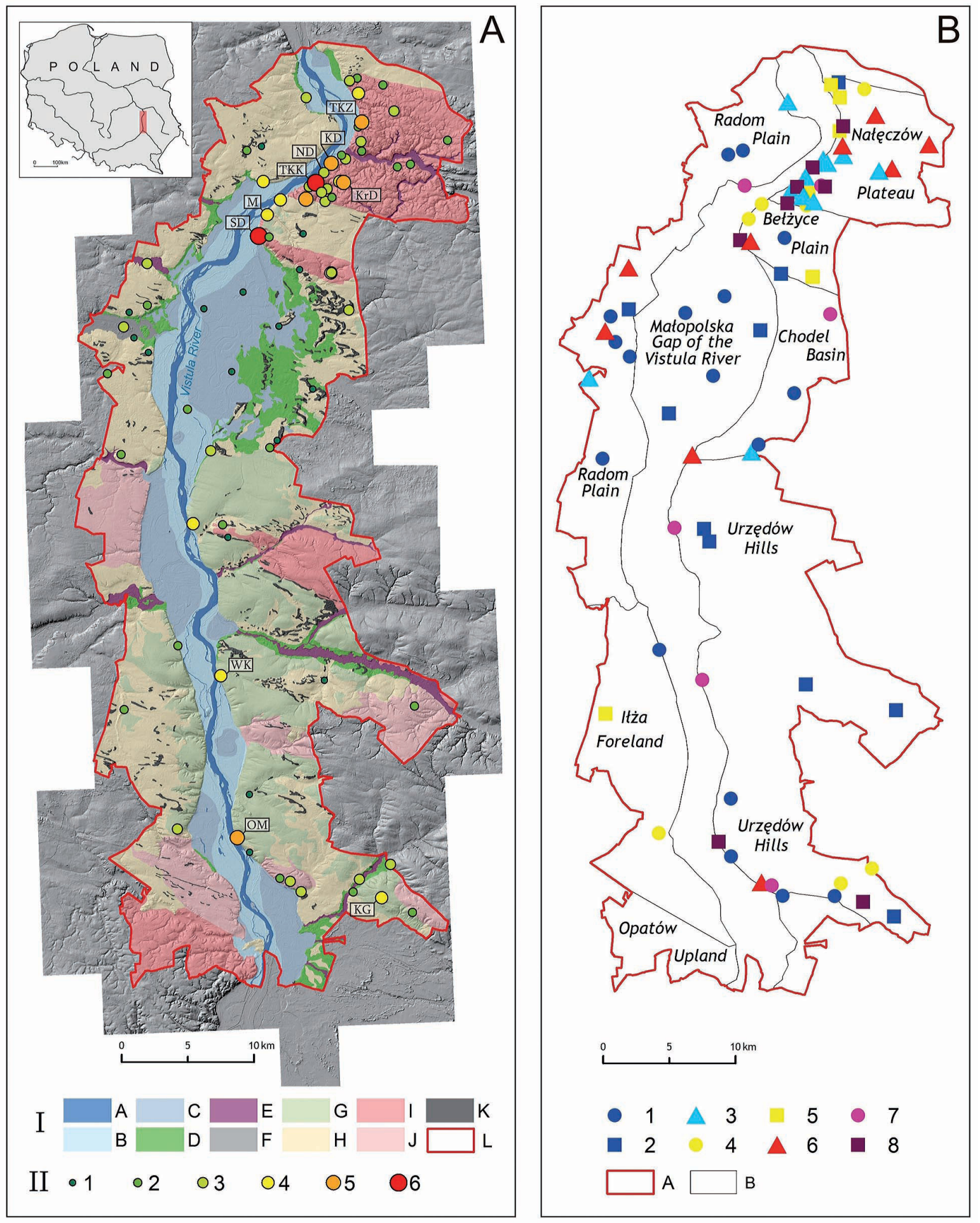

Fig. 1A: Location of the geomorphosites against natural landscapes:

I - natural landscapes: A - Vistula River braided channel, B - braided river relief of bottom valley, C - meandering river relief of bottom valley, D - raised terrace, E - deep incised tributary river valleys, F - ice-marginal relief valley, G - denudated uplands, H - glacial and fluvioglacial plains, I - strongly dissected loess cover, J - low dissected loess cover, $\mathrm{K}$ - inland dunes, L - geopark border

II: geomorphosites classes according to the total score (crescent): 1 - total value $4 \div 6$ points ; 2 - total value $6 \div 8$ points; 3 total value $8 \div 10$ points; 4 - total value $10 \div 12$ points ; 5 - total value $12 \div 14$ points; 6 - total value $14 \div 16$ points.; TKK, SD ... - acronyms explained in the text

Fig. 1B: Distribution of sites belonging to the eight geomorphosite groups presented in Table 3 within mesoregions: A - geopark border, B - mesoregion border 
Table 1. Geomorphosite assessment criteria

\begin{tabular}{|c|c|c|c|c|}
\hline Scientific value & Educational value & Functional value & $\begin{array}{c}\text { Environmental pro- } \\
\text { tection value }\end{array}$ & Tourist value \\
\hline Scientific knowledge & Representativeness & Accessibility & $\begin{array}{c}\text { Legal protection } \\
\text { status }\end{array}$ & Cultural value \\
\hline Rarity & Educational use & $\begin{array}{c}\text { Presence of tourist } \\
\text { infrastructure }\end{array}$ & $\begin{array}{c}\text { Current status } \\
\text { of site }\end{array}$ & $\begin{array}{c}\text { Additional attrac- } \\
\text { tions }\end{array}$ \\
\hline Diversity & $\begin{array}{c}\text { Existing educational } \\
\text { products }\end{array}$ & Local products & $\begin{array}{c}\text { Current and potential } \\
\text { risks }\end{array}$ & Aesthetic value \\
\hline Degree of degradation & & & Ecological value & Viewpoints \\
\hline
\end{tabular}

ingly, Kubaliková chose a set of the most important values from the perspective of the geotourist function. In the present study, we modified the Kubalikova's method according to the peculiar characteristics of the assessed area. The assessment was carried out based on 18 criteria divided into five groups (Table 1). Each criterion was assessed according to a five-point scale: 0.0, 0.25, $0.5,0.75,1.0$. Thus, the highest possible score for a geomorphosite was 18 points, whereas in terms of individual values the highest scores were 3 or 4 points.

We assessed all geomorphosites (76) located within the planned Geopark Vistula River Gap (Fig. 1), using field data collected by the authors during execution of the project of Vistula River Gap geopark. Loess relief-related (slope) sites (26) predominated among the investigated localities but there was also a relatively large proportion of aeolian forms (18 sites). Sites related to fluvial relief (9), fluvioglacial relief (6) and tectonic relief (3) were clearly less numerous. Viewpoints (14) represented a separate category.

Cluster analysis methods were employed during grouping of geosites. In order to group the geosites according to the five categories (scientific, educational, functional, environmental protection and tourist value), it was necessary to use a method enabling the creation of groups of sites in an n-dimensional space. In the case of the data above, it was a five-dimensional space. Dendrograms were used to illustrate multidimensional cluster analysis. Ward's method was used to calculate the distances between the individual clusters because it ensured the clearest identification of clusters (Fig. 2). The analysis was carried out using symbolic algebra software Mathematica.

\section{Results}

The spatial distribution of geomorphosites is uneven: a clear majority is located in the northern part of the proposed geopark, and a second cluster is linked with the southern part of the Vistula River Gap. Geomorphosites occur rarely in the central part of the geopark, mainly in the eastern part of the area (Fig. 1A).

In the overall assessment, most sites (52\%) have low geotourist value (up to 8 points). These are evenly distributed across the entire geopark. Sites of medium and high value (38\%, 8 to 12 points) occur mainly in the extreme north and south of the geopark. Geomorphosites of the highest value, linked primarily with the right-hand side of the Vistula valley, occur almost exclusively in the north-eastern part. There are only seven such sites, with a score from 12 to 16 points (Fig. 1B).

Viewpoints and slope forms are sites with the highest scores. A high rating was also given to the

Table 2. Mean ratings of geosites by genetic group (expressed in \% of the maximum score)

\begin{tabular}{|l|c|c|c|c|c|c|}
\hline \multirow{2}{*}{ Forms } & \multicolumn{5}{|c|}{ Value } & \multirow{2}{*}{ Overall score } \\
\cline { 2 - 6 } & Scientific & Educational & Functional & $\begin{array}{c}\text { Environmental } \\
\text { protection }\end{array}$ & Tourist & 57 \\
\hline Slope & 57 & 46 & 46 & 37 & 37 & 33 \\
\hline Aeolian & 32 & 23 & 30 & 52 & 35 & 41 \\
\hline Fluvial & 47 & 30 & 27 & 42 & 42 & 39 \\
\hline Fluvioglacial & 40 & 26 & 36 & 65 & 60 & 58 \\
\hline Tectonic & 67 & 46 & 50 & 57 & 70 & 55 \\
\hline Viewpoints & 57 & 32 & 40 & & & 37 \\
\hline
\end{tabular}




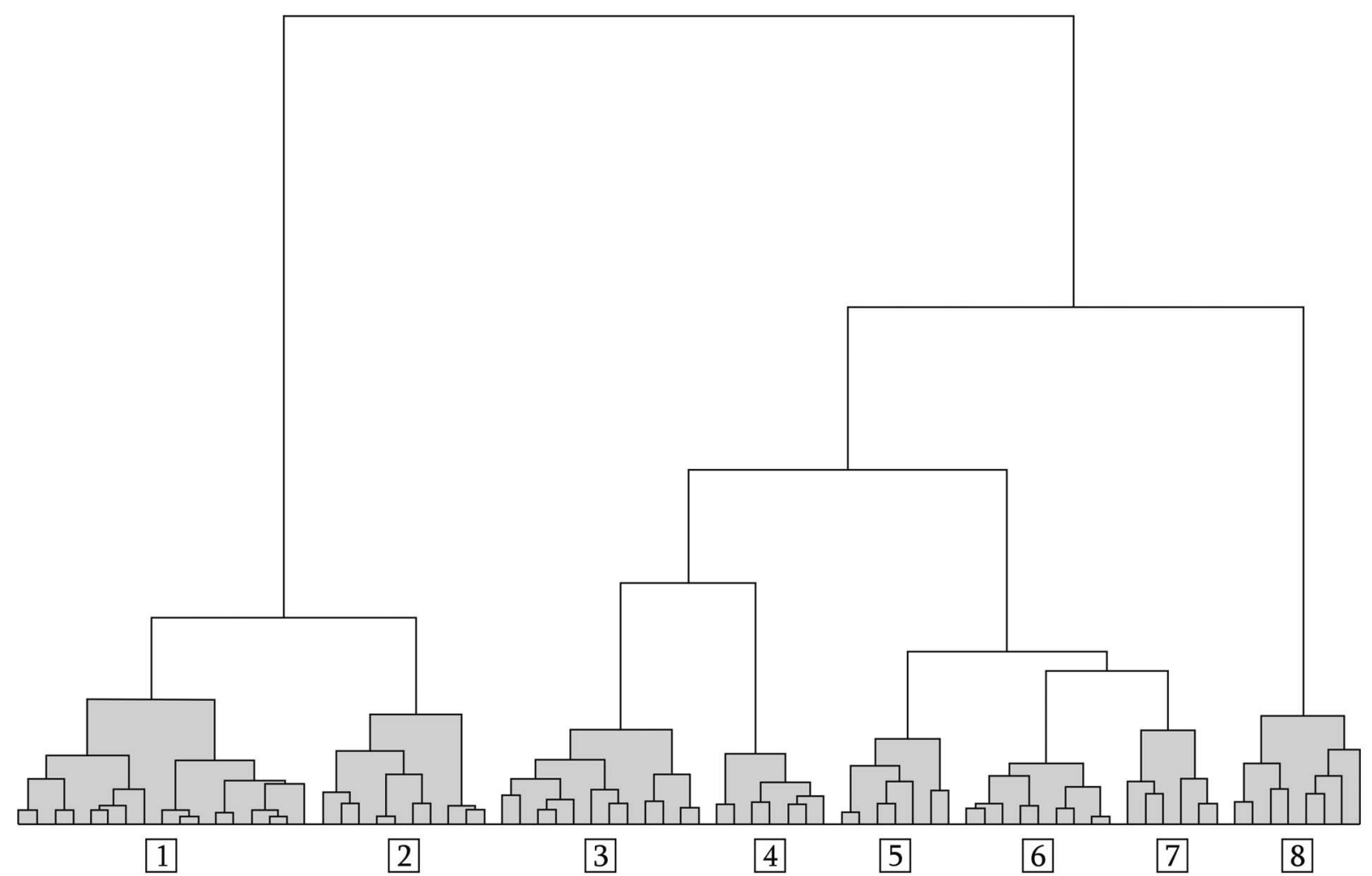

Fig. 2. Dendrogram for 76 geomorphosites under study (comp. Fig. 1B and Table 3)

few tectonic forms, often comprising viewpoints. Aeolian forms (Table 2) had the lowest score. On average, geosites received from 30 to $60 \%$ of the maximum score; the score for the top five sites ranged from 70 to $86 \%$.

The highest overall score was obtained for the following sites: Góra Trzech Krzyży in Kazimierz (viewpoint, score: 15.25; TKK at Fig. 1A), Skarpa Dobrska (tectonic form, viewpoint, score: 14.5; SD at Fig. 1A), Góra Trzech Krzyży in Zbędowice (viewpoint, score: 13.5; TKZ at Fig. 1A), Kamienny Dół (gully, score: 13.25; KD at Fig. 1A), Korzeniowy Dół (gully, score: 12.75 ; KrD at Fig. 1A). Four aeolian and two fluvial forms were among the lowest rated geosites (score $<5$ points).
The highest scientific value was found for the following sites: Skarpa Dobrska (tectonic form, viewpoint, score: 4.0), Kamienny Dół (gully, score: 3.5), Opoczka Mała (viewpoint, score: 3.5; $\mathrm{OM}$ at Fig. 1A), Kamienna Góra (viewpoint, tectonic forms, score: 3.5; KG at Fig. 1A), Wałowice Kolonia (fluvial forms, score: 3.5; WK at Fig. 1A).

In terms of educational value, the following geomorphosites received the highest rating: Kamienny Dół (gully, score: 3.0), Korzeniowy Dół (gully, score: 3.0), Skarpa Dobrska (tectonic form, viewpoint, score: 2.75), Góra Trzech Krzyży in Kazimierz (viewpoint, score: 2.75), Góra Trzech Krzyży in Zbędowice (viewpoint, score: 2.75).

Table 3. Characteristics of the geomorphosite groups identified

\begin{tabular}{|c|c|c|c|c|c|c|c|}
\hline Group & $\begin{array}{c}\text { Number } \\
\text { of sites }\end{array}$ & $\begin{array}{c}\text { Scientific } \\
\text { value }\end{array}$ & $\begin{array}{c}\text { Educational } \\
\text { value }\end{array}$ & $\begin{array}{c}\text { Functional } \\
\text { value }\end{array}$ & $\begin{array}{c}\text { Environmental } \\
\text { protection value }\end{array}$ & Tourist value & $\begin{array}{c}\text { Variety } \\
\text { of forms }\end{array}$ \\
\hline 1 & 17 & low & low & medium & medium & low & low \\
\hline 2 & 10 & medium & medium & low & low & medium & high \\
\hline 3 & 12 & medium & medium & very high & medium & medium & high \\
\hline 4 & 7 & medium & medium & high & high & high & medium \\
\hline 5 & 7 & medium & medium & very high & medium & medium & low \\
\hline 6 & 9 & high & high & low & high & medium & medium \\
\hline 7 & 6 & high & high & high & medium & high & very high \\
\hline 8 & 8 & very high & very high & very high & very high & very high & medium \\
\hline
\end{tabular}


In terms of functional value, the highest rating was awarded to: Góra Trzech Krzyży in Kazimierz (viewpoint, score: 3.0), Kamienny Dół (gully, score: 2.5), Norowy Dół (gully, piping forms, score: 2.5 ; ND, Fig. 1A).

The highest tourist value was found for the following sites: Góra Trzech Krzyży in Kazimierz (viewpoint, score: 4.0), Góra Trzech Krzyży in Zbędowice (viewpoint, score: 3.75), Skarpa Dobrska (tectonic form, viewpoint, score: 3.5), Męćmierz (viewpoint, score: 3.0; $\mathrm{M}$ at Fig. 1A), Kamienna Góra (viewpoint, tectonic forms, score: 3.0$)$.

The use of dendrogram for the 76 sites enabled us to identify eight distinct groups whose distances from the other groups were considerably greater than the distances between the sites within each group (Fig. 2). Based on the mean for the extreme points in a cluster, it was possible to ascribe a specific scientific, educational, functional, environmental protection and tourist value to each of the groups identified. Then each group was ascribed a relative low, medium, high or very high rating (Table 3). The most numerous are sites belonging to groups 1, 2, 3 (51\% of the sites), characterised by low or average value. Most of them are situated in the central part of the geopark. A considerable number of these sites can also be found in the north-eastern part. Sites belonging to groups 6, 7 and 8 (30\% of the sites), characterised by high or very high value, occur primarily in the northern part of the geopark. They are clearly less numerous in the central and southern part (Fig. 1B).

Groups 1 and 2 (27 sites) characterised by low scientific and educational value and other value

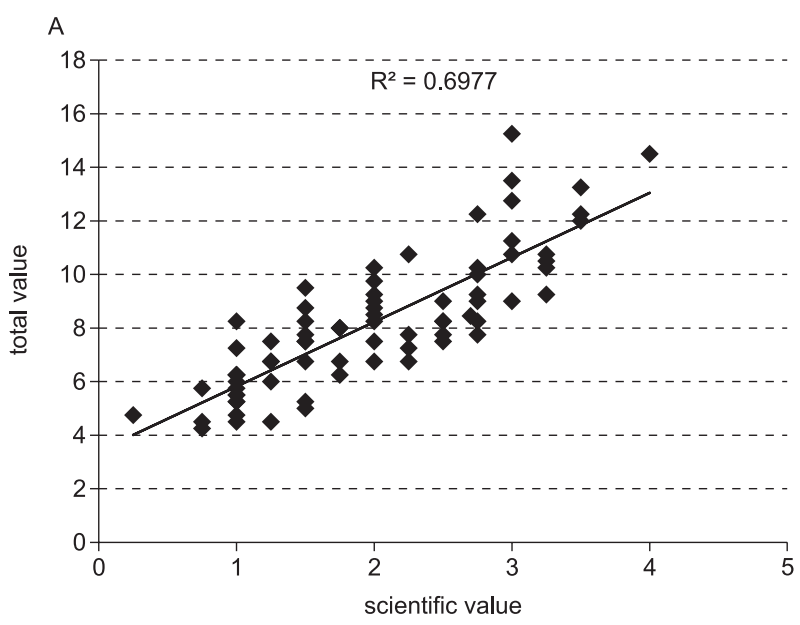

categories can be regarded as sites of local significance and with limited potential for increased significance for geotourism. Aeolian forms predominate here ( 15 sites). Groups 3 and 5 are characterised by slightly higher values; the functional value in these groups is very high. This group contains 14 gully forms. What sets groups 3 and 5 apart is the diversity of forms: high in group 3 , low in group 5. In group 4, the scientific and educational values are similar to the previous groups (medium), but the other values, including tourist value, are slightly higher (high). This group primarily consists of viewpoints. Group 6 is mainly comprised of slope forms of high scientific and educational value. On the other hand, the functional value of sites in this group is low and the tourist value is medium. Group 7 comprises the most varied set of sites characterised by high value in all categories. Group 8 consists of eight sites of very high value in all categories. It comprises sites in the area of Kazimierz Dolny and the southern escarpment of the Lublin Upland. The group consists of viewpoints (4), slope forms (3) and a tectonic form (1). Some of them are frequently visited while others, despite their high rating, are almost unknown.

A clear link (positive correlation $r^{2}=0.69$ ), was found between the scientific value and the overall score of a geomorphosite resulting from its evaluation (Fig. 3A). Such a correlation also occurs between the scientific and educational value, $\mathrm{r}^{2}=0.52$ (Fig. 3B). There is no correlation between the scientific and tourist value and between the scientific and functional value, while numerous geomorphosites are characterised by

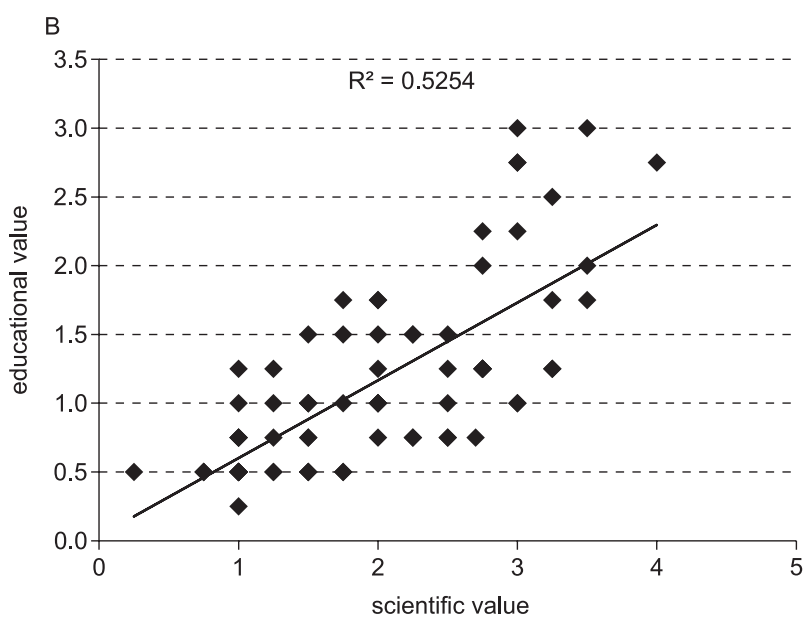

Fig. 3. Correlation between: A - the scientific value and the total value, B - the scientific value and the educational value 
low accessibility and low attractiveness to tourists. No distinct correlation was found between the scientific value and the protection of the sites and their exposure to external hazards (environmental protection value).

\section{Discussion}

The methods used made it possible not only to assess the spatial variation of geotourist values but also to propose specific, varied measures for the individual groups of sites, aimed at raising their geotourist standing. This concerns primarily groups of medium (high) value. The educational value can be enhanced by expanding the information resources (academic research), while the functional value can be raised by developing tourist infrastructure and, in some cases, accessibility. In the highest rated group of sites, six geosites owe their strong standing to their location in the Kazimierz Landscape Park and the resulting appearance in maps, pamphlets and guidebooks to educational trails. Historic sites attracting many tourists also have a significant influence. In promotion of many geosites, it seems advisable to emphasize their occurrence in the vicinity of historic cultural sites. The lack of correlation between scientific value and environmental protection indicates the need to analyse at which geosites protection should be extended despite the absence of significant hazards. The public belief is that a protected site is valuable and this very fact encourages people to become familiar with it.

The highest rated sites are located in the immediate vicinity of the town of Kazimierz Dolny, although high value does not always translate into tourists' familiarity with the sites as exemplified by Skarpa Dobrska, very little known among visitors to the Lublin region (Zgłobicki, Baran-Zgłobicka 2013). The situation is similar for the highly rated geomorphosites in the Annopol area. Some of them are hardly ever visited by tourists. The previously conducted questionnaire surveys indicate that tourists are interested in the Vistula River Gap and loess gullies in the Kazimierz Dolny area, although the respondents referred to types of forms rather than specific localities.

There is a clear spatial variation in the location of geosites that are most suitable for geotourism development. Most of these geosites are located in the Kazimierz Dolny area with its well-developed infrastructure and large numbers of visitors. At the same time, the presence of several sites of similar value in the southern part of the planned geopark gives an opportunity to create another centre of geotourism, in the Annopol area. It could be based in the old phosphate mine after making it accessible to visitors.

It is worth noting that viewpoints obtained high scores in the assessment carried out as a part of this study; some of them are well known and frequented by many visitors. These sites are surely very well-suited for the presentation of information (interpretation boards) on geoheritage. Some loess gullies constitute another group of geosites frequented by many tourists and suitable for educational functions while having high scientific value.

According to the assessment, viewpoints and elements of loess relief (primarily gullies) are the highest rated sites. Vantage points offer an opportunity to observe tectonic and fluvial forms. This indicates that slope, fluvial and structural aspects should be the key distinguishing characteristics of the planned geopark and popularization of geomorphological knowledge.

In order to ensure sustainable tourist development in the entire area of the geopark and not just in the immediate vicinity of Kazimierz Dolny, it is necessary to undertake several measures promoting the value of other parts of the planned geopark where "geotourist gems" can also be found. Incorporated into more extensive trails, they can become an attraction for those visitors to the area who are interested in inanimate nature.

One should stress the influence of scientific value on the overall geotourist assessment of an individual site even though some other values (functional or tourist) are independent. This indicates the necessity for a thorough examination of the potential geopark areas and dissemination of this knowledge in the form of scientific and popular science publications. On this basis it will be possible to develop the other values (educational, didactic, environmental protection). The fact that geosites with the highest scientific value are usually characterised by the highest tourist value is a positive phenomenon. 
It should be emphasized that, until now, not a single geotourist trail has been designated in the area described. There is also a lack of interpretation boards presenting the elements of the area's geomorphological heritage. Only one brochure with information on major geosites has been published. It seems that establishing a geopark is the only way to obtain the funds necessary to create geotourist infrastructure (designation and marking of the trails, creation of interpretation boards and publications) and thus promote the geoheritage of the area.

\section{Conclusions}

Cluster analysis is a valuable tool to identify groups of geomorphosites in relation to which various measures should be taken.

There is an high impact of scientific value on the overall geotourist assessment.

The most valuable geomorphosites are located within northern and southern part of the projected geopark.

Some of the highly ranked geomorphosites are not well known by tourists.

Viewpoints that have received the highest total score should be used for the promotion of geoheritage first.

\section{Acknowledgments}

The study was financed from funds for scientific research by the Faculty of Earth Sciences and Spatial Management, Maria Curie-Sklodowska University in Lublin.

\section{References}

Alexandrowicz Z., Kućmierz A., Urban J., Otęska-Budzyn J., 1992. Waloryzacja przyrody nieożywionej obszarów i obiektów chronionych w Polsce (Evaluation of inanimate nature of protected areas and objects in Poland). Polish Geological Institute, Warsaw.

Dmytrowski P., Kicińska A., 2011. Waloryzacja geoturystyczna obiektów przyrody nieożywionej i jej znaczenie w perspektywie rozwoju geoparków (Geotourism valuation of unbiotic objects and their signifi cation in prospect of geopark development). Problemy Ekologii Krajobrazu 29: 11-20.

Feuillet T., Sourp E., 2011. Geomorphological Heritage of the Pyrenees National Park (France): Assessment, Clustering, and Promotion of Geomorphosites. Geoheritage 3: 151-162. DOI 10.1007/s12371-010-0020-y

Harasimiuk M., Warowna J., Gajek G., 2013. Zróżnicowanie krajobrazów projektowanego Geoparku Małopolski Przełom Wisły (Projected Geopark Małopolska Gap of Vistula River landscape's diversification). Monitoring Środowiska Przyrodniczego 14: 27-35.

Kubaliková L., 2013. Geomorphosite assesment for geotourism purposes. Czech Journal of Tourism 2: 80-104. DOI: 10.2478/cjot-2013-0005.

Narkiewicz M., Dadlez R., 2008. Geologiczna regionalizacja Polski - zasady ogólne i schemat podziału w planie podkenozoicznym i podpermskim (Geological regional subdivision of Poland: general guidelines and proposed schemes of sub-Cenozoic and sub-Permian units). Przeglą Geologiczny 56: 391-397.

Necheş I. M., 2013. From geomorphosite evaluation to geotourism interpretation. Case study: the Sphinx of Romanian`s Southern Carpathians. GeoJournal of Tourism and Geosites 12(2): 145-162.

Panizza M., 2001. Geomorphosites: concepts, methods and example of geomorphological survey. Chinese Science Bulletin 46, Suppl. Bd: 4-6.

Pralong J. P., 2005. A method for assessing tourist potential and use of geomorphological sites. Geomorphologie: relief, processus, environement 1(3):189-196.

Pożaryski W., 1997. Tektonika powaryscyjska obszaru świętokrzysko-lubelskiego na tle struktury podłoża (Post-Variscan tectonics of the Holy Cross Mts-Lublin region (central Poland) and the substrate structure). Przegląd Geologiczny 45(12): 1265-1270.

Radwanek-Bąk B., Laskowicz I., 2012. Ocena georóżnorodności jako metoda określenia potencjału turystycznego obszaru (Assessment of geodiversity as a method of geotourism potential assessment). Annales UMCS, B, 67(2): 77-95. DOI: 10.2478/v10066-012-0021-8

Reynard E., Fontana G., Kozlik L., Scapozza C., 2007. A method for assessing scientific and additional values of geomorphosites. Geographia Helvetica 62(3): 148-158.

Solarska A., Jary Z., 2010. Geoheritage and Geotourism Potential of the Strzelin Hills (Sudetic Foreland, SW Poland). Geographica Pannonica 14(4): 118-125.

Warowna J., Migoń P., Kołodyńska Gawrysiak R., Kiebała A., Zgłobicki W., 2013: Geomorphosites of Poland - the role played by the Central Register of Geosites. Landform Analysis 22: 117-124. DOI: 10.12657/landfana.022.010.

Zgłobicki W., Baran-Zgłobicka B., 2013. Geomorphological Heritage as a Tourist Attraction. A Case Study in Lubelskie Province, SE Poland. Geoheritage 5: 137-149. DOI: 10.1007/s12371-013-0076-6.

Zgłobicki W., Baran-Zgłobicka B., Ziółek M., Ziółek G., 2005. Atrakcyjność wizualna krajobrazu polskich parków narodowych a ich wartości przyrodnicze (Scenic beauty of Polish National Parks landscape and their natural values). Parki Narodowe i Rezerwaty Przyrody 24: 135-151. 